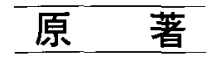

Video-oculography によるメニエール病症例の電気性眼振の解析

$$
\text { 小宮卓・都筑 俊寬 }
$$

\title{
Analysis of Galvanic Nystagmus in Patients with Ménière's Disease by Video-oculography
}

\author{
Takashi Komiya, Toshihiro Tsuzuku \\ Department of Otolaryngology, Teikyo University School of Medicine
}

Galvanic nystagmus (GN) has been studied with regard to equilibrium. However, the nystagums-provoking mechanism has not been clarified. In this study, we considered Meniere's disease (MD) to be a unilateral vestibular disorder model, and analyzed GN recorded in MD by video-oculography.

The subjects were 10 patients with MD (38-60 years). The patients were divided into an acute group of 5 patients who had the last insult within 2 weeks and a chronic group of 5 patients who had the last insult more than 4 weeks before. Stimulation of the cathode using direct current at 1,2 , or $3 \mathrm{~mA}$ for $30 \mathrm{sec}$ was alternately performed on the affected and healthy sides in the acute and healthy subjects as controls using the mean frequency of nystagums and slow phase velocity.

The mean frequency of nystagmus caused by stimulation at $2 \mathrm{~mA}$ on the affected side was significantly lower in the acute group $(0.453 \pm 0.354 \mathrm{~Hz})$ than in the control group $(1.088 \pm 0.437 \mathrm{~Hz})(P<0.05)$. The mean slow phase velocity was also lower in the acute group $(1.494 \pm 1.223 \mathrm{deg} / \mathrm{sec})$ than in the control group $(5.053 \pm 5.236 \mathrm{deg} / \mathrm{sec})$ $(\mathrm{P}<0.1)$. There were no significant differences in the mean frequency of nystagmus and slow phase velocity caused by stimulation between the healthy side in the acute group and the control group. The mean frequency of nystagmus and slow phase velocity caused by stimulation on the affected and healthy sides were not significantly different between the chronic and control groups.

The reduction of responses on the affected side in the acute MD stage suggested the involvement of the vestibule and semicircular canal as the stimulation receptors of GN examination. In the chronic stage, since the condition was considered to be the steady state without vertigo, the results were considered to be due to central and peripheral compensation.

Key words: galvanic nystagmus, Ménière's disease, video-oculography 
用して以来, 基礎的・臨床的研究が多数報告され た。わが国でも，時田らりによって，平衡機能障 害時に沶いて，末梢性か後迷路性かの鑑別に有用 との報告がされた。GNによる平衡機能評価は， 現在普及している galvanic body sway test に比較 し，体を支持する筋力の個体差，姿勢をたてな打 す運動能力の差などの要因が加わらず，より定量 的な評価が可能と思われる。

しかし，GN は，その解発機構が不明であるこ と, 臨床使用上の刺激条件の不統一, 成績の解釈 の相違などの理由から，他の眼振検查と比較して 臨床的にあまり応用されていなかった。さらに GN 存解析するにもたり ENG（electronystagmography）では電気刺激が記録に淈入してしまうた め不可能であったことが最大の問題点であった。

この問題を解決し, 電気性眼振検査を他の眼振 検査と同様に広く臨床的に利用するため, 刺激と 反応との関係を明らかにし，将来的に病的状態で の記録の基準となるデータをつくる目的で，われ われは赤外線 CCD カメラによる眼球運動の記録 装置（video-oculography）を用い健常成人のGN を記録解析し報告した2)。その結果健常人では， 眼振は 1 2 $\mathrm{mA}$ を閾值として陰極向きに解発さ れた。 $4 \mathrm{~mA}$ 以上では通電時の疼痛のため検査を 拒否する場合があったが，検查可能な範囲に和い て, 眼振数抢よび平均緩徐相速度は, 電流が強く なるにしたがって医湶形に増加した2り。

GN の研究にあたり，眼振解発機構および電気 刺激受容器に関する考察和不可欠である。本稿で は，この課題に対してメニエール病（以下，メ病 と略）を一側性内耳障害のモデルと考光，メ病症 例の GN を記録解析した。

\section{方法と対象}

GN 検査に打ける通電刺激法には被刺激側（左 右の耳）と電気極性との組み合わせで，両耳両極 法 (Biauricular-bipolar), 一耳両極法 (Monoauricular-bipolar)，両耳単極法 (Biauricular-monopolar), 一耳単極法 (Monoauricular-monopolar) の 4 通りがある。内耳機能正常成人の場合, 雨耳両 極法および一耳除極法では，眼振は陰極向きに解 発される。本実験では健側と患側を交互に刺激 し, 反応を比較する必要から利便性を考兄，両耳 両極法を採用した。刺激電極虫日本光電社製 $\mathrm{X}$-transrode ${ }^{\mathrm{TM}}$ を使用した。刺激装置は日本光電
社製の SEN-3301 を使用した。刺激条件は，平流 直流により1，2，3 mA で30秒間，患側特よび健 側を交互に陰極で刺激し，反対側を陽極とした。 誘発された眼振は, 赤外線 CCDカメラを介し 眼球運動を追跡し, Biodigital 社製の VEONYS

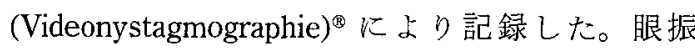
数, 平均緩徐相速度を富士通 FMVS42051に上り 経時的に解析した。

対象は，当科通院中および入院中のメ病患者 10 名（38～60歳）とした。メ病患者は，最終発作か ら 2 週間以内の患者 5 名を急性期群，4週間以上 経過した患者 5 名を慢性期群とし，健常人の眼振 数，平均緩徐相速度と比較した。被験者には，本 実験の原理，目的および安全性について説明し， 同意を得て施行した。通電中，電極部の痛みが不 快な際は，すぐ申し出るよう話し，直ちに赛験を 中断した。自発眼振のある症例てついては，測定 值から自発眼振成分を除外するため絶対值の差,

すなわち，自発眼振（S）と同側の電気性眼振 (G) の眼振数扣よび緩徐相速度は G-S, 自発眼 振（S）と反対側の電気性眼振 (G) の眼振数掠 よび緩徐相速度は G+S とし健常人と比較した。 健常人とメ病患者の比較にはマン・ホイット二検 定を用い，検定を行なった。

\section{結 果}

刺激中の解発眼振波形の一例を示寸。(図 1) 健常人 14 人から得られた平均眼振数招よび平均緩 徐相速度の值とメ病患者急性期群 5 名, 慢性期群 5 名の值を比較した（図 $2 \mathrm{a}, \mathrm{b}, \mathrm{c}, \mathrm{d}$ )。記録中 10例中 7 例の患者に自発眼振を認めた。ボラン ティアを募って計測した健常人と異なり,メ病患 者では, $3 \mathrm{~mA}$ 刺激時に電極部の痛みで検查を拒 否する例があり，検定に必要なデータ数が得られ なかったため, $1 \mathrm{~mA}$ および $2 \mathrm{~mA}$ について健常 人と比較した。急性期メ病患側の眼振数は, $2 \mathrm{~mA}$ 刺激に打いて，健常人の $1.088 \pm 0.437 \mathrm{~Hz}$ から $0.454 \pm 0.354 \mathrm{~Hz} \quad(P<0.05)$ へと有意に低 下乙ていた。緩徐相速度子健常人の $5.053 \pm$ $5.236 \mathrm{deg} / \mathrm{sec}$ から $1.494 \pm 1.223 \mathrm{deg} / \mathrm{sec}(P<0.1)$ へと低下していた（図 $3 \mathrm{a}$ )。急性期健侧刺激時の 眼振数扣よび緩徐相速度は健常人と有意差はな かった（図 $3 \mathrm{~b}$ )。慢性期患側刺激の緩徐相速度打 よび眼振数は, 健常人の值と有意差はなかった (図 $3 \mathrm{c}$ )。慢性期健側刺激の緩徐相速度扣よび眼 


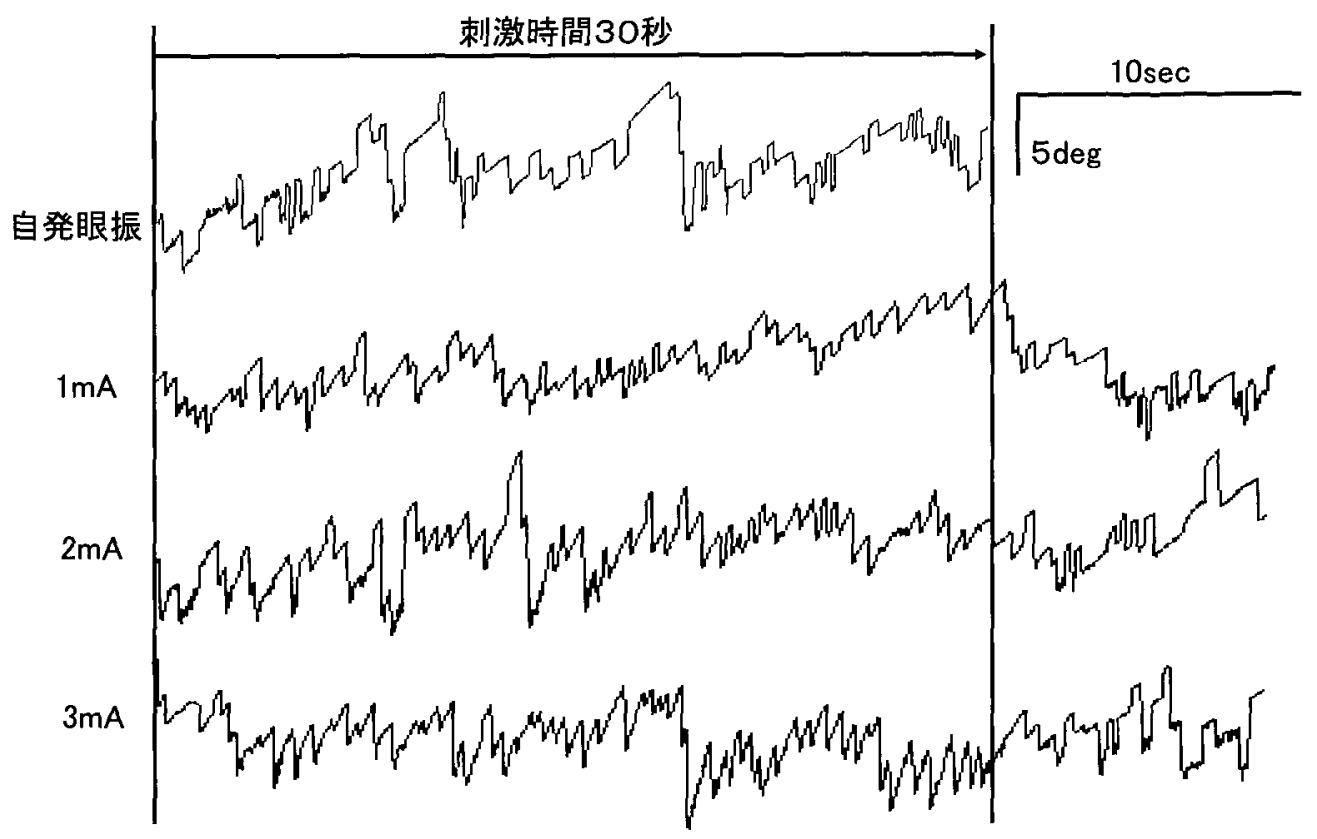

図 1 急性期左メニエール病患者（58歳女性）の患耳刺激時の GN

平成17年 1 月 1 日め㢳作が出現し，1月6日 GN を記録した。記録時，左向き自発眼振を認めた。 刺激により患側向きの GN が解発された。自発眼成分は除去し，健常人と比較した。

振数も, 健常人の値と有意差はなかった（図 $3 \mathbf{d}$ )。

\section{考察}

われわれは，自発眼振成分と GN の平均緩徐 相速度括よび眼振数に执いて, 絶対值の差をとり 健常人とメ病患者を比較した。Pfaltz 健常人と 50 名のメ病患者の GN を解発閾値に扔 いて比較し，両者に差はないと報告した。GN の 研究が盛んに行われていた1960から70年代使用さ れていた PENG は眼振の方向性も不明瞭な記録 であり，それ以前は肉眼観察にたよっていた。定 量的解析には，限界があったと思われ，そのデ一 タをもとになされた考察にも疑問がのこる。近年 の研究では，Brackmann 54) が，一耳単極刺激比 よる GN で健常人とメ病患者を比較している。 その結果, 彼らは, 緩徐相速度の対数値に打いて 健常人とメ病患者との美はないと報告した。彼ら は不関電極を前腕儿置き，一力われわれは反対側 の乳様突起に陽極を置いて和り，われわれの方法 では，非刺激側の反応が混在している可能性は否 めない。しかし，Brackmannらの方法では，不 関電極が前腕にあるがゆえに十分に前庭系が刺激 されていないとも思われた。これらの報告に対し
て，われわれの比較では急性期のメ病症例では患 側の平均緩徐相速度扣よび眼振数ともに健常人よ り低值を示した。メ病の病態生理は内リンパ水腫 であるので，測定值の差は健常人とメ病急性期の 前庭機能の差と考えられた。

従来, 患側と健側の前庭機能の比較は温度眼振 検查による評価が一般的であった。メ病と温度眼 振検査結果との関係についてはいくつかの報告が ある。Pulec ${ }^{5)}$ は病勢が強い時には，前庭系の抑 制によって，温度刺激汇対する反応は両側とも低 下し，病初期には膨張した球形囊がアブミ骨底板 に接触しているので，温度刺激が内リンパに対し てより有効に作用し，障害側は反応充進を示す。 また, 温度刺激検查に対する永久的な反応穴進は, 罹患期間の長い例沉しばしばみられると述べた。 渡辺 ${ }^{6)}$ は, 温度眼振検查上, 半規管麻㽻 (以下, CP と略), 眼振方向優位性 (以下, DP と略) の 2 種が区別されるが，CP はむしろ疾患の成熟期 または終末期に多くみられ活動期にはDPがしば しば現れる。休止期には左右差が減少して正常と 区別しがたい場合も多いと述べた。田口ら7は, 64症例に反復して温度眼振検査を行い, 特に DP 
a) 急性期患側刺激
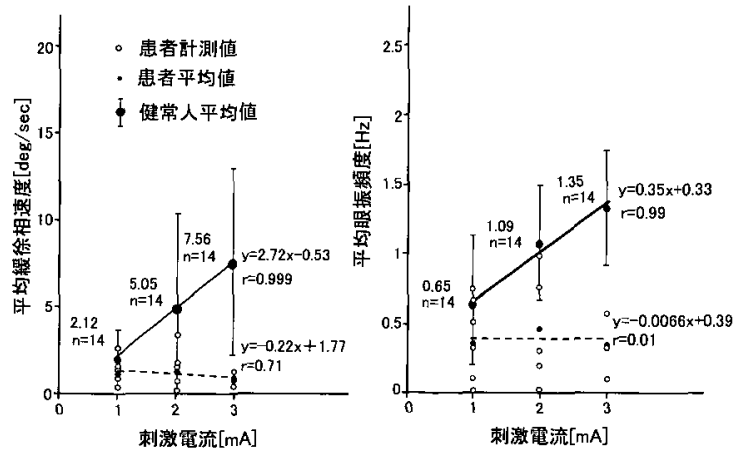

c）慢性期患側刺激
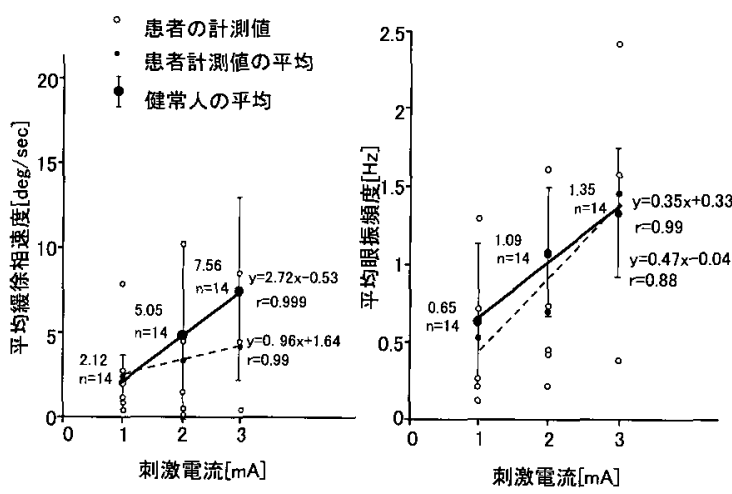

b）急性期健側刺激
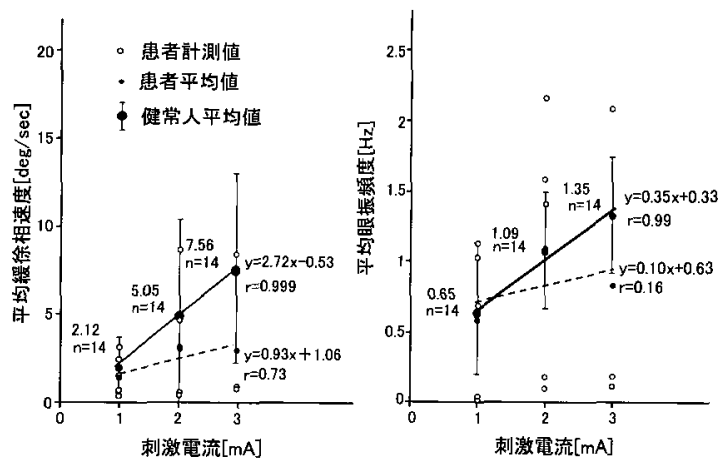

d) 慢性期健側刺激
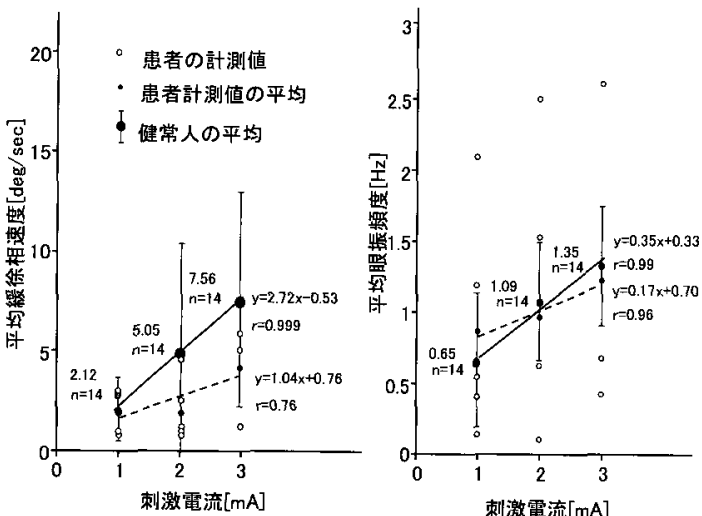

図2 健常人と又病病期別の GN の比較

健常人に扮いて平均緩徐相速度拈上び眼振数は刺激電流の強さに依存して線形性に增加する傾向を示し た。○はメ病症例の測定値, ○は平均值を示す。健常人とメ病症例を最小二乗法による回帰直線で比較し た。

a）急性期メ病症例の患側刺激時の平均緩徐相速度おょび眼振数は，健常人より低值を示す傾向があった。

b）急性期メ病症例の健例刺激時の平均緩徐相速度扣上び眼振数は，健常人と同等であった。

c）慢性期メ病症例の患側刺激時の平均緩徐相速度おょび眼振数は，健常人と同等であった。

d）慢性期メ病症例の健側刺激時の平均緩徐相速度抢よび眼振数は，健常人と同等であった。

に着目し，初期には必ず DP があり，その後の経 過から，DP が持続する型，DP から正常範囲に 移行する型, DP から CP に移行する型に分類し た。このよ5に, メ病では，その経過中に内耳機 能の变化を示唆する温度眼振検査結果の変動が報 告されており，統一した見解がないが，いずれの 報告でも患側と健側の温度眼振の反応の差により 前庭機能障害の存在を示唆している。今回の実験 では，同意を得られた患者が少なく，温度眼振検 查と GN 検査の関係までは比較検討できなかっ た。このため, メ病の温度眼振検査について統一
した見解がない現時点では，直流電流が後迷路を 刺激していることは否定できない。しかし，われ われの解析では，GN 検査における急性期入病患 側耳の反応は検定上の有意差を認め, メ病の病態 生理は内リンパ水腫であるので，測定值の差は前 庭和よび半規管機能低下を反映している可能性が あると考えられた。これらのことにより，GN 検 査の受容体の一つとして前庭就よび半規管の関与 が示唆された。

一方において，慢性期の患者については，患側 刺激，健側刺激ともに健常人の計測値と同等で 
a) 急性期患側刺激
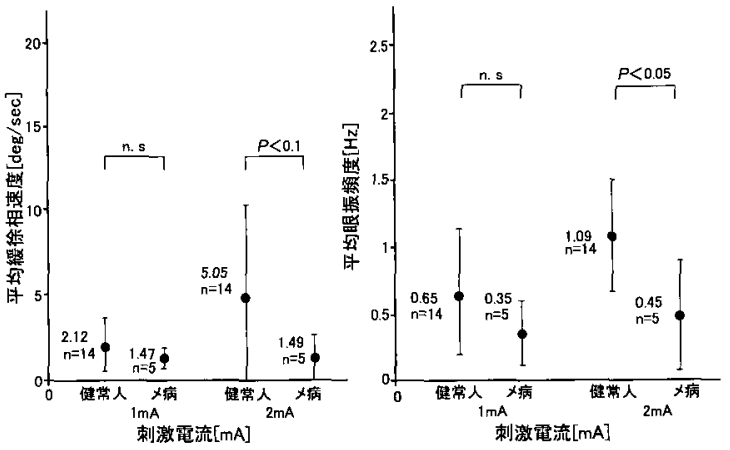

c) 慢性期患側刺激

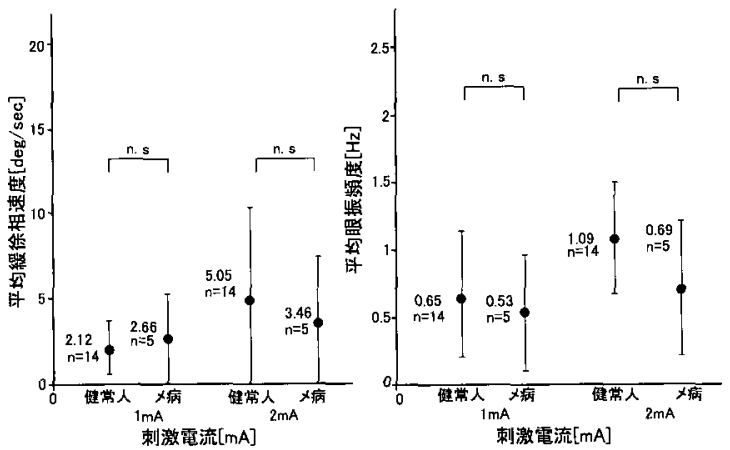

b）急性期健側刺激

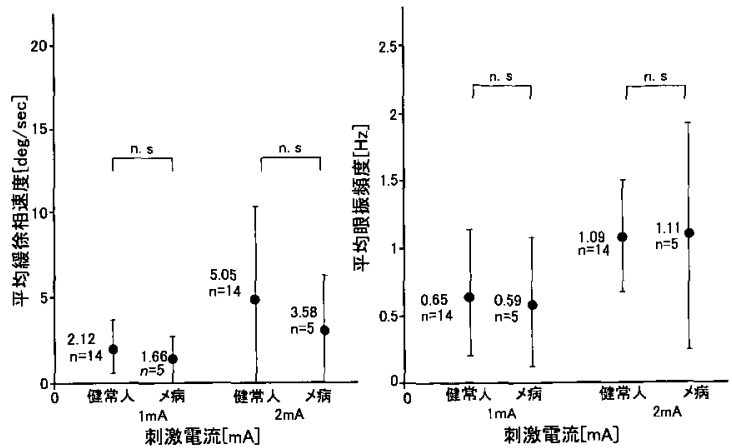

d) 慢性期健側刺激

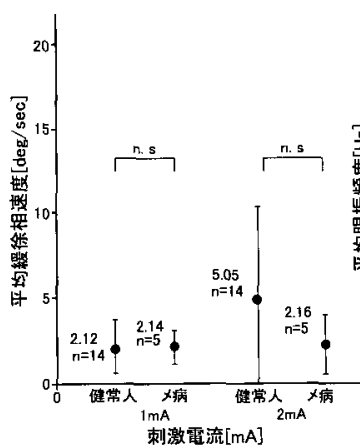

図 3 健常人と又病病期別の GN の比較（検定結果）

健常人とメ病患者の測定值に拈㚈る，マン・ホイットニ一の順位和検定の結果を示す。 $3 \mathrm{~mA}$ では痛みを 訴学施行できない患者も市り，㛟定不能であった。

a） $2 \mathrm{~mA}$ では急性期メ病症例の患側刺激時の平均緩徐相速度拉よび眼振数は，健常人上り低值を示した。 $1 \mathrm{~mA}$ では健常人とメ病患者との間に有意差はなかった。

b) 急性期メ病健側刺激時の平均緩徐相速度扣上び眼振数は，健常人と有意差はなかった。

c）僈性期又病患側刺激時の平均緩徐相速度および眼振数は，健常人と有意差はなかった。

d）慢性期火病健側刺激時の平均緩徐相速度招上び眼振数は，健常人と有意差はなかった。

あった。慢性期では臨床上もめまいがなく定常状 態と考えられるのでこれは中枢和よび末梢の代償 機能の結果と考兄られた。このことによって， GN 検査は前庭代償の評価に束使用できる可能性 が示唆された。

神経は on-off 刺激に反応して興奮性を示す。 経皮的に頭部に加光られた持続的直流電流刺激 が，どのように前庭系を刺激して GNのような 持続性の前庭反応を発現するかについては前庭神 経の自家放電の変化に関係するという Bárány の 電気緊張説が有名である。この刺激機序につい て, Goldberg ら ${ }^{87}$ は, サルの外リンパ空を陰極 電極で刺激した実験結果から，前庭神経の自家放 電レベルは末梢端（distal part）に流れる電流に より変化し，末梢端を外向き切方（axonから myelin 万向）に電流が流れる場合に興奮刺激， 反対方向では抑制刺激が起こると述べ，解説して いる。こうした経緯から，電気刺激検查は後迷路 性障害の診断に役立つとされてきた。これに対 し, Schneider ら9) は, ヒトで $2 \mathrm{~mA}$ の電気刺激 での GN 波形を，頭部前屈にて重力方向を軸と した頭部回転刺激で再現安試み一致させている。 彼らはこれらの結果から， $2 \mathrm{~mA}$ の $\mathrm{GN}$ は半規管 からの反応が強いと推定した。われわれの結果で も，GN 検査に乱好る健常人之急性期メ病患側耳 の反応に有意差を認めたことから，GNには末梢 
前庭器の反応も含まれていると考えられた。

以上から, 電気性眼振検查の受容器の一つとし て末梢前庭器官が関与し, その前庭終末臟器の障 害の評価，および一側性前庭障害に打敌る中枢性 代償状態の評価に为有用と考えられた。

本論文主旨は，第63回日本めまい平衡医学会 (前橋) および第23回バラニ一学会（パリ）で発 表した。

文献

1) 時田 喬, 青木 守, 渡辺忠彦, 他: 電気眼 振検査法の検討。耳鼻臨床 60 増 1: 38-57, 1967

2 ) 小宮 卓, 都筑俊寛, 吉本 裕: 赤外線眼球 運動記録装置による電気性眼振の解析.

Equilibrium Res 61: 446-450, 2002

3) Pfaltz CR: Vestibular diagnosis in Ménière's disease. Arch Otorhinolayngol 212: 321-329, 1976

4) Brackmann T, Ranft U: The galvanic test in the diagnosis of vestbular disease. HNO 37: 174-178, 1989

5) Pulec JL: Ménière's disease: results of a two and one-half-year study of etiology, natural history and results of treatment. Laryngoscope 82: 1703-1715, 1972

6) 渡辺前：メニエール病の予後について，耳 鼻展望 6: 238-246,1963

7) 田口喜一郎, 菊川正人, 中野知幸 : メニエ儿病長期観察例の温度眼振反応。耳鼻臨床 73: 1893-1898, 1980

8 ) Goldberg JM, Smith CE, Fernandez C: Relation between discharge regularity and responses to externally applied galvanic corrents in vestibular nerve afferents of the squirrel monkey. J Neurophysiol 51: 1236-1256, 1984

9) Schneider E, Glasauer S, Dieterich M: Comparison of human ocular torsion patterns during natural and galvanic vestibular stimulation. J Neurophysiol 87: 2064-2073, 2002

原稿到着：平成17年12月13日

別刷請求先: 小宮 卓

干173-8605 東京都板橋区加賀2-11-1

帝京大学医学部耳鼻咽喉科学教室 